\title{
Nucleation Reduction Strategy of (Brushite) CHP Crystals in SMS Media and Its Characterization Studies
}

\author{
G. Kanchana ${ }^{1}$, P. Sundaramoorthi ${ }^{2}$, R. Santhi ${ }^{3}$, S. Kalainathan ${ }^{4}$, G.P. Jeyanthi ${ }^{1}$ \\ ${ }^{1}$ Department of Bio-Chemistry, Avinasliilingam University, Coimbatore, India. \\ ${ }^{2}$ Department of physics, Aringar Anna Government Arts and Science College, \\ Namakkal. (E-mail: sundara78@ rediffmail.com) \\ ${ }^{3}$ Department of Physics, MEC, Mallasamudram (W), Namakkal, India. \\ ${ }^{4}$ Department of physics, VIT, Vellore, India
}

\begin{abstract}
Kidney stone consist of various organic, inorganic and semi organic compounds. Mineral oxalate monohydrate and di-hydrate is the main inorganic constituent of kidney stones. However, the mechanisms for the formation of calcium oxalate kidney stone are not clearly understood. In this field of study there are several hypothesis including nucleation, crystal growth and or aggregation of formation of COMH, AOMH (Ammonium oxalate monohydrate), $\mathrm{CODH}$, and AODH (Ammonium oxalate di-hydrate) crystals. The author has reported the effect of some urinary species such as ammonium oxalates, calcium, citrate, proteins and trace mineral. The kidney stone constituents are grown in the kidney environments, the silica gel medium (SMS) provides the necessary growth simulation (in-vivo). In the artificial urinary stone preparation (growth) or crystal growth, growth parameter identification with in the different chemical environments is carried out. In the present study, CHP (calcium hydrogen phosphate) crystals are grown in three different growth faces to attain the total nucleation reductions. As an extension of this research, many characterization studies have been carried out, and the results are compared and reported.
\end{abstract}

Key words: Renal stones, MHP, calculi, surface morphology, growth parameters, trace elements, SDP, AMHP, Brushite.

\section{INTRODUCTION}

Most kidney stones consist of an organic matrix with bio-minerals. The organic matrix has a composition that remains constant regardless of the type of crystals that make up the stone $[1,2]$. The kidney stone accounts for approximately $4 \%$ of the weight of a calculus [3]. Most of the current knowledge of matrix composition emerges from the analysis of the $30 \%$ of matrix substances that are soluble [4]. The matrix has been described as a heterogeneous material composed of inorganic minerals, proteins, lipids, carbohydrates and cellular components [5]. Proteins are the major constituents of stone 
matrices and are the principal macromolecules in urine [6]. Urinary proteins with the potential to adjust crystallization of calcium oxalate and calcium phosphate are TammHorsfall protein, nephrocalcin, osteopontin, calprotectin, human serum albumin and urinary prothrombin fragment [5]. Most of these proteins are produced by the kidney, chiefly by the renal tubular epithelial cells [5]. Other protein such as calprotectin, is produced by granulocytes and are commonly released at the sites of inflammation, has also been of concern in stone formation [5]. The bio-mineral contains hard minerals like $\mathrm{Ca}, \mathrm{Ba}, \mathrm{Sr}, \mathrm{Mg}$ and phosphates or its mixtures. The most common and important human body element of all the stones is calcium. Naturally calcium is found with concentrations of $8.9-10.1 \mathrm{mg} / \mathrm{ml}$ in the plasma [7]. Hypercalciuria is a biological syndrome defined as the excretion of calcium in the urine of more than $0.1 \mathrm{mmol} / \mathrm{kg} / 24$ hours of major minerals dietary manipulation. Hypercalciuria is the most common metabolic abnormality in patients with nephrolithiasis [8]. In general hypermineralueria raises urine super saturation with respect to the solid phase of mineral complex with phosphate, enhancing the probability of self-nucleation and growth into clinically significant stones.

Urinary mineral excretion is continuously influenced by dietary intakes of calcium, sodium, protein, carbohydrates, alcohol, ammonium, trace element and potassium [9]. A mineral has been shown to bind to oxalate to form mineral oxalate monohydrate. Thus, mineral has been shown to affect the concentration of oxalate. In addition, oxalate is a major component of urinary stones and its urinary concentration plays an important role in stone formation. Even a small increase in urinary oxalate has a significant impact on mineral oxalate saturation. Although primary hyperoxaluria is relatively uncommon, patients with mineral oxalate stones have some degree of hyperoxaluria [10]. So, reducing the oxalate concentration would be helpful to most stone patients. More amounts of oxalate can be obtained from foods such as nuts, chocolate, and dark green leafy vegetables [11]. Citrate concentrations of plasma range from 0.05$0.03 \mathrm{mmol} / \mathrm{l}$ and it exits as an alkaline citrate [12]. Citrate inhibits crystallization of mineral oxalate and mineral phosphate by several mechanisms. (a) It decreases urinary saturation of mineral salts by complexion minerals and reducing ionic minerals concentration [13]. (b) Citrate directly inhibits spontaneous precipitation of mineral oxalate [14], agglomeration of mineral oxalate [15], crystal growth of mineral phosphate [13] and heterogeneous nucleation of mineral oxalate by monosodium ureate [16]. (c) Citrate converts glycoprotein to an active disaggregated state probably by enhancing their inhibitor activity against the crystallization of calcium salts [17-18]. Due to the prohibitive role of citrate mentioned above, patients with hypocitraturia would be at a higher risk of developing renal stones. This fact indicates that hypocitraturia is an important factor for stone formation.

The kinetic process of $\mathrm{COMH}$ (calcium oxalate monohydrate) nucleation and crystal growth requires super saturation [19], which can be obtained by excretion of the reactants in the urine (calcium, oxalate and water). Few molecules are combined together to form clusters. In the early step, clusters do not show a high degree of internal ordering [20] the longer time they exist, however, their degree of ordering increases by replacing internal salvation bonds by solid ion-ion bonds [21]. Gradually, clusters become crystal embryos [21]. Above a critical size, embryos will grow into stable nuclei, and below 
some critical size, crystal embryos are too small and will reduce over all free energy by dissolving [21]. The size of the nuclei is usually $100 \AA$ or less [21]. Once crystal nucleus has reached its critical size and super saturation ratio remains above one, over all free energy is decreased by adding new crystal components to the nucleus (self/spontaneous growth). This process is technically called as crystal growth [37].

Proteins (macromolecules) influence nucleation, crystal growth and aggregation of COM within the urinary system. It is reported that macromolecules can modify COM crystal habit $[5,38]$. Crystal growth is slow in some directions since macromolecules adsorb on specific directions and prevent them from lattice ions [5.23and 24]. Face (-101) of COM crystal is more active, presents more closely packed $\mathrm{Ca}_{2}^{+}$atoms and has significantly more adsorptive characteristics for many macromolecules [5,39]. Specific adsorption of macromolecules can also bind non-specifically covering the crystal thin with plate-like square edges. Macromolecules can also bind non-specifically covering the crystal surfaces and retarding crystal growth. Khan [40] reported that adsorbed macromolecules could promote heterogeneous nucleation by attracting calcium ions to their calcium-binding domains with all the standard faces [40].

\section{MATERIALS AND METHODS}

The silica gel also known as water glass was used in the present work as an intermediate growth medium. SMS (ARG-sodium meta silicate powder) was added to the double distilled water, in the ratio of 1:1, mixed and stirred well and kept undisturbed for few days to allow sedimentation. Then the clear top solution was filtered and stored in a light protected glass container. This is known as a stock solution [22]. The gel densities of $1.03-1.06 \mathrm{gm} / \mathrm{cc}^{3}$ were used. Simple test tubes of $25 \mathrm{~mm}$ diameter and $150 \mathrm{~mm}$ length were used. The concentrations of orthophosphoric acid used in these experiments were $0.5 \mathrm{~N}, 1 \mathrm{~N}$ and $2 \mathrm{~N}$. The supernatant solution of calcium chloride concentration varied form $0.5 \mathrm{M}$ to $2 \mathrm{M}[23,24]$. One of the reactant orthophosphoric acids were mixed in the gel solution. The gel solution was taken as one third of its volume of the test tubes and after the gel set, the supernatant solution of calcium chloride was added slowly along the sides of the test tubes. The mixtures diffuse through the gel medium, which contains orthophosphoric acid. The chemical reaction takes places, which leads to the growth of CHP crystal.

The chemical reaction is

$\mathrm{Ca}^{2+}+\mathrm{HPO}_{4}{ }^{2-}+2 \mathrm{H}_{2} \mathrm{O}=>\mathrm{CaHPO}_{4} \cdot 2 \mathrm{H}_{2} \mathrm{O}+$ Waste 


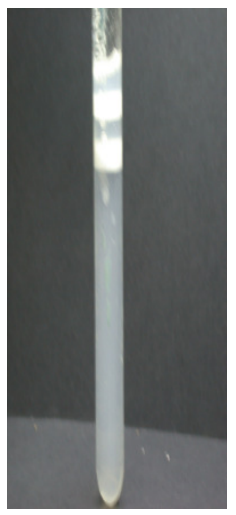

Fig-1

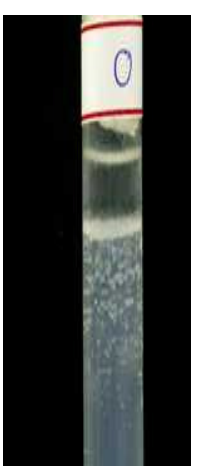

Fig-2

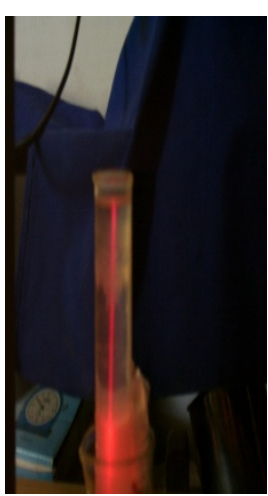

Fig-3

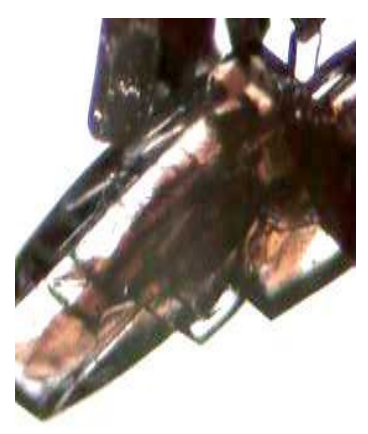

Fig-4

Fig-1 Growth of crystal in room temperature

Fig-2 Growth of crystal in sunlight medium

Fig-3 Growth of crystal in laser light medium

Fig-4 Grown Brushite crystal (Harvested)

Table 1. Growth parameters of CHP crystals (SDP)

\begin{tabular}{|c|c|c|c|c|c|c|c|}
\hline $\begin{array}{l}\text { SMS } \\
\text { gel } \\
\text { dens } \\
\text { ity } \\
\text { gm } \\
/ \mathrm{cc}^{3}\end{array}$ & $\begin{array}{l}\text { Ortho } \\
\text { phospho } \\
\text { ric acid } \\
\text { concentr } \\
\text { ation }\end{array}$ & $\begin{array}{l}\mathrm{Gel+} \\
\mathrm{H}_{3} \mathrm{PO}_{4} \\
\mathrm{pH} \\
\text { value }\end{array}$ & $\begin{array}{l}\text { Gel setting } \\
\text { time }\end{array}$ & $\begin{array}{l}\text { Supernatant } \\
\text { Concentration } \\
\mathrm{CaCl}_{2} \\
\text { (M) }\end{array}$ & $\begin{array}{l}\text { Nucleatio } \\
\mathrm{n} \\
\text { observed } \\
\text { in hours }\end{array}$ & $\begin{array}{l}\text { Gro } \\
\text { wth } \\
\text { perio } \\
\text { d } \\
\text { days }\end{array}$ & $\begin{array}{l}\text { Types of crystal } \\
\text { observed/ } \\
\text { Harvested crystal } \\
\text { size. }\end{array}$ \\
\hline \multirow[b]{2}{*}{1.05} & $0.5 \mathrm{~N}$ & $\begin{array}{l}6.5 \\
6.9 \\
7.2\end{array}$ & $\begin{array}{c}24 \mathrm{hrs} \\
\mathbf{1 0} \mathbf{~ m i n} \\
34 \mathrm{hrs}\end{array}$ & $\begin{array}{c}2 . \\
\text {-do- } \\
\text {-do- }\end{array}$ & $\begin{array}{c}16 \\
\mathbf{2 0} \\
100\end{array}$ & 70 & $\begin{array}{ll}\text { Many } & \text { poly } \\
\text { crystals, } & \end{array}$ \\
\hline & $1 N$ & $\begin{array}{l}6.5 \\
7.0 \\
7.5\end{array}$ & $\begin{array}{l}14 \text { hrs } \\
\mathbf{1 ~ h o u r ~} \\
28 \text { hrs }\end{array}$ & $\begin{array}{l}\text {-do- } \\
\text {-do- } \\
- \text { do- }\end{array}$ & $\begin{array}{l}10 \\
06 \\
64\end{array}$ & 80 & \multirow{2}{*}{$\begin{array}{l}\text { Dendrite } \\
\text { crystals, } \\
\text { Liesegang rings } \\
\text { are observed }\end{array}$} \\
\hline \multirow{2}{*}{1.04} & $0.5 \mathrm{~N}$ & $\begin{array}{l}6.4 \\
6.9 \\
7.3\end{array}$ & $\begin{array}{c}\mathbf{3 4} \text { hrs } \\
\text { 1hr } \\
48 \mathrm{hrs}\end{array}$ & $\begin{array}{l}\text {-do- } \\
\text {-do- } \\
- \text { do- }\end{array}$ & $\begin{array}{l}\mathbf{1 0} \\
\mathbf{1 2} \\
38\end{array}$ & 60 & \\
\hline & $1 N$ & $\begin{array}{l}6.5 \\
6.8 \\
7.3\end{array}$ & $\begin{array}{l}16 \mathrm{hrs} \\
\mathbf{1 ~ h r} \\
24 \mathrm{hrs}\end{array}$ & $\begin{array}{l}\text {-do- } \\
\text {-do- } \\
\text {-do- }\end{array}$ & $\begin{array}{l}24 \\
\mathbf{1 0} \\
64\end{array}$ & 65 & Single crystals \\
\hline
\end{tabular}




\section{RESULT AND DISCUSSION}

\subsection{FTIR spectral analysis of CHP crystals}

CHP-FTIR spectrum was recorded by using SHIMADZU FTIR-435 instrument. The FTIR spectrometer have $\mathrm{KBr}$ pellets sample holder and $\mathrm{KBr}$ detector. The $\mathrm{KBr}$ pellet samples were used and the absorption frequencies start in the range from $600 \mathrm{~cm}^{-1}$ to $4000 \mathrm{~cm}^{-1}$. The spectrum was interpreted with the earlier reported value [25-27]. The absorption bonds, absorption frequencies and percentage of transmittance were compared with the reported values. The values are tabulated in Table 2.

Table 2. Comparative table of FTIR-CHP crystal.

\begin{tabular}{|c|c|c|c|c|}
\hline S.No. & Bonds/Vibrations & $\begin{array}{l}\text { Reported } \\
\text { values cm }^{-1}\end{array}$ & $\begin{array}{l}\text { Observed } \\
\text { values } \mathrm{cm}^{-1}\end{array}$ & $\begin{array}{l}\% \text { of } \\
\text { transmittance }\end{array}$ \\
\hline 01. & $\begin{array}{l}\text { Calcium with Hydrogen } \\
\text { bond }\end{array}$ & 3477 & 3492.8 & 9 \\
\hline 02. & $\begin{array}{l}\mathrm{H}-\mathrm{O}-\mathrm{H} \quad \text { Symmetric } \\
\text { stretching bond }\end{array}$ & 1620 & 1649.0 & 13 \\
\hline 03. & $\mathrm{O}-\mathrm{H}$ out of plane bond & 662,781 & $\begin{array}{l}663.5 \\
792.7\end{array}$ & $\begin{array}{l}17 \\
14\end{array}$ \\
\hline 04. & $\begin{array}{l}\mathrm{P}-\mathrm{O}-\mathrm{P} \text { asymmetric } \\
\text { stretching bond }\end{array}$ & $\begin{array}{l}987 \\
874 \\
794\end{array}$ & $\begin{array}{l}985.6 \\
873.7 \\
792.7\end{array}$ & $\begin{array}{c}7 \\
13 \\
14\end{array}$ \\
\hline 05 . & $\mathrm{PO}_{4}$ bond & 1000 to 1100 & $\begin{array}{c}1134 \\
1060.8\end{array}$ & $\begin{array}{l}5 \\
6\end{array}$ \\
\hline 06. & $\begin{array}{l}(\mathrm{H}-\mathrm{O}-) \mathrm{P}=\mathrm{O} \text { bond (strong } \\
\text { absorption) } \\
\text { phosphates }\end{array}$ & $\begin{array}{l}665 \\
577 \\
525\end{array}$ & $\begin{array}{l}663.5 \\
576.7 \\
526.5\end{array}$ & $\begin{array}{c}17 \\
9 \\
7\end{array}$ \\
\hline & Week absorption & 2375 & 2345.3 & 22 \\
\hline 07. & $\mathrm{HPO}_{4}{ }^{2-}$ & 1722 & 1649 & 13 \\
\hline
\end{tabular}

\subsection{Atomic Absorption Spectroscopy of CHP Crystals (AAS)}

AAS spectrum was recorded by Magnesium flame technique. The spectrum was recorded as concentration versus absorption. Fig.5 shows the AAS spectrum. The characterization concentration used here was $7.245 \mathrm{mg} / \mathrm{l}$. The characterization concentration and residuals are tabulated in Table 3. 


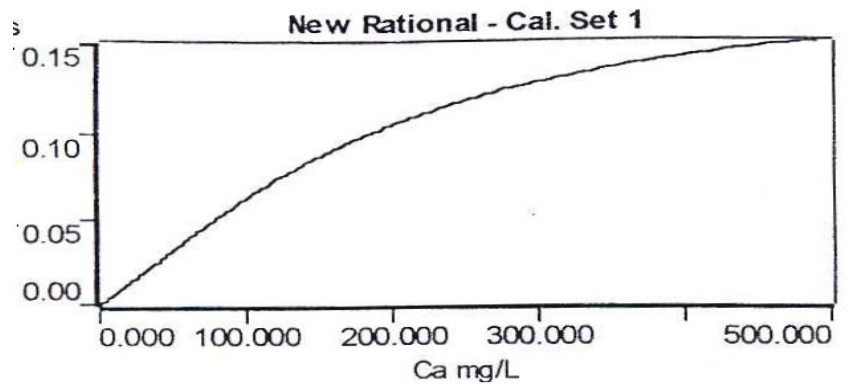

Fig. 5. AAS of Brushite crystal.

Here three standard concentrations were used and the corresponding observations were tabulated. Two samples were prepared; one gave the results in out of calibration range, and another one gave reliable data. Following procedure was used to calculate the percentage of composition present in the CHP crystal.

Table 3. Concentration and residuals of CHP crystals.

\begin{tabular}{|l|l|l|}
\hline S.No & \multicolumn{1}{|c|}{$\begin{array}{c}\text { Calculated } \\
\text { concentration mg / 1 }\end{array}$} & \multicolumn{1}{|c|}{ Residuals } \\
\hline 1. & 0.703 & -0.703 \\
2. & 97.414 & 2.588 \\
3. & 207.150 & -7.150 \\
4. & 489.464 & 10.536 \\
\hline
\end{tabular}

\subsection{Thermo Gravimetric (TGA and DTA) Analysis of CHP Crystals}

The TGA and DTA of CHP crystals were carried out by STA 11500-PLTS instruments. The CHP crystal of $2.439 \mathrm{mg}$ sample was taken to the TGA process. The TGA was started from room temperature to $900^{\circ} \mathrm{C}$ by heating at a constant rate. The percentage of weight of sample remaining present in the CHP sample at a particular temperature was tabulated in Table 4.

\subsection{Etching Study of CHP Crystals}

A well-grown $\mathrm{CHP}$ crystal was immersed in $\mathrm{HCl}$ solution at a desired concentration. The dissolution of CHP crystal depends upon on the etchant concentration, temperature, crystal morphology, etching time etc. The etch pits were photographed. Fig.6 shows the etch pits of CHP crystal [28-31]. The etch pit patterns were observed as spirals, dendrites, allies and straights. 
Table 4. Thermal decomposition of CHP crystals.

\begin{tabular}{|c|c|c|c|}
\hline \multirow{2}{*}{ Points } & \multicolumn{2}{|c|}{ TGA } & DTA in ${ }^{\circ} \mathrm{C}$ \\
\cline { 2 - 3 } & Temperature & \% of CHP crystal present & \\
\hline 1 & 35 & 100 & \\
2 & 95.96 & 99.71 & 93.01 \\
3 & 126.32 & 95.63 & 122.41 \\
4 & 181.86 & 86.86 & 146.42 \\
5 & 205.23 & 81.02 & 185.33 \\
6 & 425.87 & 77.68 & 200.53 \\
7 & 491.69 & 74.45 & 257.11 \\
8 & - & - & 453.03 \\
\hline
\end{tabular}

\subsection{Scanning Electron Microscopic Study of CHP Crystals}

A well-grown CHP single crystal was selected for the investigation of surface morphology of the grown crystal by using SEM. The SEM photograph was obtained in the version S-300-I instrument. The sample named as VCA-600 kept in lobe middle; the data size was $640 \times 480 \mu \mathrm{m}$. The magnification of SEM was about 250 times. SEM acceleration voltage was 25000 volts and the sample was kept in highly vaccum state. 18200-micrometer work distance was maintained and monochromatic color modes were employed. Fig.7 shows the SEM pattern and surface morphologies of CHP crystal [32$35]$.

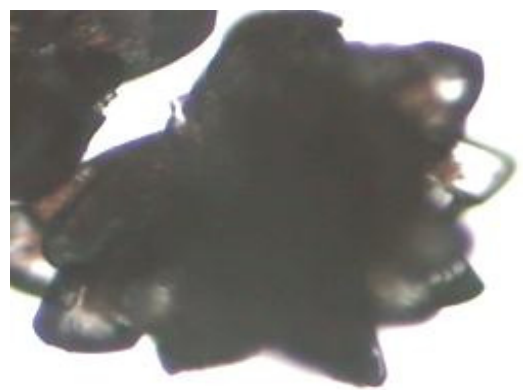

Fig-6 Etch pit pattern of CHP crystal

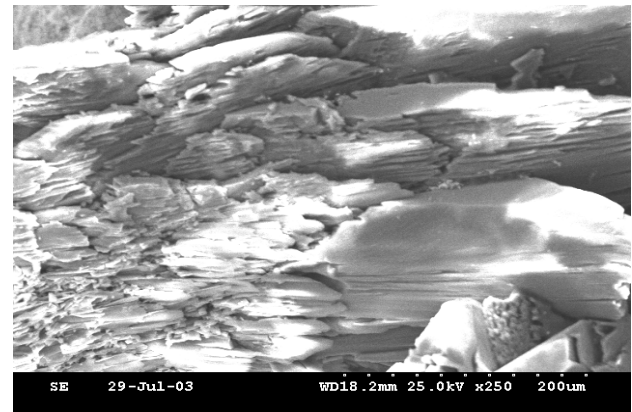

Fig-7 SEM pattern of CHP crystal

\subsection{X-Ray Diffraction}

The XRD results revealed that the grown crystal was single phase of (CHP) brushite crystal. The XRD pattern and diffraction indices of the crystal were recorded. The unit cell parameters are calculated and the cell parameters of CHP crystals are a $=7.0672 \AA, b=18.4739 \AA, c=23.7069 \AA$ and $\alpha=\beta=\gamma=90^{\circ}$. The crystal system is found to be orthorhombic. 


\section{CONCLUSION}

The CHP crystals were grown at room temperature and exposed to sunlight and laser medium. It was found that, CHP crystal nucleation rate was reduced more in the laser exposed medium than the sunlight-exposed medium, which is due to variation of super saturation. FTIR-spectrum recorded the functional group frequencies of CHP crystal constituents. These results were recorded and compared with the reported values. Chemical etching was done at room temperature, which revealed the grown crystal defects. SEM analysis was also done and it reveals the surface morphology of CHP crystal. The decomposition temperature and percentage of weight loss of the grown crystal was recorded by TGA and DTA analysis. XRD data gives the CHP grown crystal cell parameters and its structure.

\section{REFERENCES}

[1] S.R.Khan,P.O.Whalen, and P.A.Glenton,J.Cryst.Growth 134,211(1993).

[2] W.H.Boyce,Am.J.Med. 45 (5), 673 (1968).

[3] H.G.Tiselius,Clin.Chim.Acta.122, 409 (1982).

[4] R.W.Marshall and W.G.Robertson,Clin.Chim.Acta.72, 253 (1976).

[5] S.R.Khan,Urol.Int 59, 59 (1997).

[6] R.L.Ryall,A.M.F.Stapleton,in calcium oxalate in Biological system,Eds.S.R.Khan (CRC press) (1995).

[7] C.G.Duarte and F.G.Knox, in text book of renal pathophysiology, (Harper and Row ,(1978).

[8] F.L.Coe,J.H.Parks, and J.R.Asplin,N.Engl.J.Med.327,1141(1992)

[9] Maurice Audran and Erick Legrand,Joint Bone spine 67 (6),509 (2000).

[10] Y.Ogawa,T.miyazato, and T.Hataano,World j.Surgery 24 (10),1154 (2000).

[11] D.S.Goldfarb and F.L.Coe, Am.Fam.Physicican.60 (8) 2269 (2000).

[12] D.P.Simpson,Am.J.Physiol.224(3), F223 (1983).

[13] J.L.Mayer andL.Hsmith,Invest.Urol 13, 36 (1975).

[14] M.J.Nicar,K.Hill and C.Y.C.pack,J.Bone ,Miner.Res.2 (3), 215 (1987)

[15] D.J.Kok,S.E.Papapoulus, and O.L.M.Bijvoet,Lancet41,1056 (1986).

[16] C.Y.C. Pakand Paterson, Arch.Intern.Med.146, 863 (1986).

[17] B.Hess,Miner.Electr.Metab 20,393 (1996)

[18] C.Y.C.Pak,Hypocitraturia; a critical review and furture direction,from $8^{\text {th }}$

European symposium on Urolithiasis-Parma,Italy,June 9-12 (1999).

[19] A.Mersmann,Crystallization technology,Hand book, $2^{\text {nd }}$ Edi. Marcel Dekker,Inc.(2000).

[20] V.A.Garten and R.B.Head,Phil.Mag.14, 1243 (1966).

[21] D.J.Kok, The role of crystallization process in mineral oxlates urolithasis, Ph.D thesis, Univerasity of Leiden (1991).

[22] Henisch, H.K. etal,J Electro Chemical. Soc.,112 (1965) 627.

[23] A.E.Alexander, and P.Honson, Colloid Science ,Clarendon Press, Oxford,(1949).

[24] W.Eitel, In:Physical chemistry of Silicate University of Chicago Press,(1954).

[25] Yean. Chin etal 'Application of IR Spectroscopy to analysis of uninary calculi J. Urol. Vol 86, (1961) 838-854. 
[26] C.M. Corns "Infrared analysis of real Calculi - a comparison with conventional Techniques"Ann. Clin. Bio-Cherm, Vol 20, (1983) 20-35.

[27] A.Hesse, D. Bach,. Stone analysis by IR spectroscopy, Clinical and laboratory Aspects, Edi.Alan Rose, University Park Press, Baltimore, (1982), 87-105.

[28] J.J.Gilman, J.,Johnsion and G.W.Sears, J.Appl.Physics., 29,(1958) 749.

[29] J.J. Gilman., etal, , J.Appl.Physics, 27,(1956)1018.

[30] J.C.Fisher, in: Dissolutions and Mechanical Properties of Crystals, John Wiley and sons, NewYork (1957).

[31] J.B. New Kirk., In:Director observation of Imperfection in crystals, Interscience Publisers, New York (1962).

[32] K. Taukamot, J. Cryst. Growth, 61, (1983) 99.

[33] H.C.Gates, Thirty years of progress in Surface Science, in: Crystal growth and characterization,(Edi),North Holland (1975).

[34] H.Bethage etal, Electron Microscopy in Solid State Physics, Elsever, Amsterdom (1987)

[35] N. Albon etal, in: Growth and Perfection of Crystals, Wiley, New York, P.44 (1958).

[36] P.Sundaramoorthi, S.Kalainathan, Asian journal of chemistry,19-4, (2007).

[37] B.D.Hess and D.J.kok, Nucleation, Growth and aggregation of stone- Forming crystals, In Kidney stones: Medical and surgical management eds.F.L.Coe et al (Lippincott-Raen.publishers), (1996).

[38] L.Addadi,A.Berman,J.Moradian-Oldk, and S.Weiner,Connect Tiss.Res.21,127-135 (1989).

[39] S.Deganello, Calcif.Tiss.Int.48, 421 (1991).

[40] S.R.khan, Urol.Int.59, 59 (1997). 